\title{
Water quality assessment of hand-dug wells in Janga, Ghana
}

\author{
Noel Bakobie1, Fuseini \\ Mohammed Awal' ${ }^{1}$, \\ and Abudu Ballu \\ Duwiejuah*2
${ }^{1}$ Department of Ecotourism and Environmental Management, Faculty of Renewable Natural Resources, University for Development Studies
2Department of Biotechnology, Faculty of Agriculture, University for Development Studies *Corresponding Author Email: abalu096@gmail.com

Access to good quality drinking water is a challenge to the people of Janga who depend on hand-dug wells water for years as the main source of drinking water. This study examined water quality of hand-dug wells in Janga in the West Mamprusi District. A total of ten water samples from five hand-dug wells were collected and analysed for physico-chemical and coliform bacteria quality using standard methods. Generally, the physicochemical parameters varied, but all were within the World Health Organisation standards for portability except turbidity. The study recorded coliform bacteria count that ranged from 0 to $211 \mathrm{cfu} / 100 \mathrm{ml}$ (total coliform); 0 to $482 \mathrm{cfu} / 100 \mathrm{ml}$ (faecal coliform); and 0 to $90 \mathrm{cfu} / 100 \mathrm{ml}$ (Escherichia coli). These exceeded WHO guideline values $(0 / 100 \mathrm{ml})$ for drinking water indicating that the hand-dug wells are not free from pollution. Coliform bacteria count indicates poor sanitary conditions in Janga, arising from poor handling of domestic wastes, especially garbage and sewage implying water from hand-dug wells is not suitable for direct human consumption. It is therefore recommended that hand-dug wells water should be treated against bacteria before usage in order to meet the millennium development goal 7.

Key words: Coliform bacteria, hand-dug wells, water quality, Ghana

\section{INTRODUCTION}

Water is a resource that is precious and vital to the existence of all living organisms, but this cherished resource is increasingly being threatened as human populations grow and demand more water of high quality for domestic purposes and economic activities (Yakubu, 2013). Safe drinking water is a human birth right as much as clean air, however much of the world's population does not have access to safe drinking water (Adefemi, 2012). Inadequate water supply is still one of the major challenges in developing countries. It has been reported that 783 million people in the world ( $11 \%$ of the total population) have no access to safe water, $84 \%$ of them live in rural areas (WHO and UNICEF, 2012). About 187 million people use surface water for drinking purposes, $94 \%$ of them are rural inhabitants and they are concentrated in sub-Saharan Africa (WHO and UNICEF, 2012).

Concerning the safety of water, research evidences has shown that many low income countries are off-track to reach target 7C of the millennium development goals for water supply and sanitation, aimed at reducing by half the proportion of people without sustainable access to safe drinking-water and basic sanitation by 2015 (WHO, 2011). In spite of increasing international awareness of and attention to water and health, water, sanitation, and hygiene challenges continue to plague the developing world (Palaniappan et al., 2008). A good number of the population in developing countries die yearly as a result of water borne diseases such as cholera, typhoid, hepatitis, diarrhoea among others (WHO, 2008). Ease of access and effortlessness of use of fresh clean water is the key to sustainable development in agriculture for food production and poverty alleviation (Gadgil, 1998).

Many water resources in deprived nations are detrimental because they harbour harmful physical, chemical and biological agents. Total coliforms and E. coli are used as indicators to assess the degree of contamination 
and sanitary quality of well water, because testing for all known pathogens is a problematic and expensive process (Nkansah et al., 2010). The scarcity of piped water has made communities to find alternative sources of water such as groundwater sources and rainwater.

Groundwater is generally less susceptible to contamination and pollution when compared to surface water bodies. However, rural dwellers hold a theoretical view that groundwater being the "safest" water; wells are found to be polluted in terms of mineral contents, particles solute, organic matter and bacteria concentration. Underground water contaminations are attributed to anthropogenic activities such as disposal of domestic, municipal and industrial waste on the land surface, in shallow excavation including septic tanks, deep wells and agricultural chemicals leach into tanks and pipelines (Adekunle, 2008). Groundwater accounts for about $98 \%$ of the world fresh water that is distributed throughout the world (Ayodele and Aturamu, 2011). The preference of groundwater as a source of drinking water in rural areas is because of its relatively better quality than river water (Obiri-Danso et al., 2009).

Janga community has been facing serious water scarcity as a result of limited freshwater resources in its catchment area resulting in many residents depending on hand-dug wells as their major source of drinking water and other domestic uses. Inadequate and inefficient pipe borne water supply has resulted in construction of hand-dug wells that have close proximity to open dumping sites, household trash, gutters (waste water channels) and therefore prone to storm water. Open defecation is increasingly becoming alarming in some sections of the community, putting residents at the risk of sanitation related diseases such as cholera, diarrhoea and typhoid among others. The open defecation, coupled with poor development plan, chronic unhygienic habits and lack of enforcement of regulations have served as a collective recipe for pollution of environmental media. Hence, the main objective of this study was to assess the water quality of hand-dug wells in Janga in the West Mamprusi District.

\section{MATERIALS AND METHODS}

\section{Study Area}

The study was carried out in Janga. Janga is one of the communities found in West Mamprusi district. It is located within longitudes $0^{\circ} 35^{\prime} \mathrm{W}$ and $1^{\circ} 45^{\prime} \mathrm{W}$ and latitude $9^{\circ} 55^{\prime} \mathrm{N}$ and $10^{\circ} 35^{\prime} \mathrm{N}$. It has a total land area of $5,013 \mathrm{~km}^{2}$ and shares boundaries with eleven districts and two regions thus Upper East and West. The district has a total population of one hundred fifty-nine thousand, one hundred and eighty-two $(159,182)$ and a population density of 32 persons per square kilometres. The White Volta and some of its tributaries have divided the district into two, the main land and the 'overseas' areas. Water logging is common at the 'overseas area' during the rainy seasons thus making the area unmotorable. There are two major climatic seasons, a short unreliable rainy season (May/ June to October) and a long dry season (October/ November to April, May). The weather between November and February is hazy which creates conducive environment for transmission of cerebrospinal meningitis.

\section{Experimental Sampling Design}

The district has about 50\% success rate of boreholes. However, when a borehole is drilled, the yield is very low but sufficient for hand-pump installation. Some communities close to the district capital are compelled to move on daily bases in search for water. During lean season, people of Janga struggle to survive in terms of water scarcity. Hand-dug wells have been found to be the most preferred option and relief (Plate 1 and 2). This is because the local people are able to sink some wells on their own which prove to be more successful than boreholes. The average depth of hand-dug wells in the study was 15 metres. Some wells do get dry in the dry season (March to June). Janga people bury their corpses in their compound houses or in the foreyards very closed to hand-dug wells.

A total of ten (10) samples were collected (between the period of 7 a.m. and 8 a.m.) from five hand-dug wells for a period of two months, from February to March, 2014. For physico-chemical samples, 1.5 litre plastic bottles were rinsed with distilled water before used for sampling. Sample bottles (freshly empty voltic bottles) were labelled A1-A5 to symbolize the hand-dug wells. The samples were stored in a cool box with ice packs to preserve the samples during transportation to the laboratory for analysis. Samples collected were transported to CSIR-Water Research Institute laboratory, Tamale for physico-chemical and coliform bacteria analysis. The samples were stored in a refrigerator at a temperature of $4{ }^{\circ} \mathrm{C}$ until completion of analysis. Test on coliform bacteria parameters was conducted within 24 hours after sampling.

\section{Physico-Chemical and Coliform Bacteria Analysis}

Water sample collected from each hand-dug well was taken to the CSIR- Water Research Institute laboratory, Tamale for physico-chemical parameters analysis using standard laboratory techniques.The $\mathrm{pH}$, temperature, electrical conductivity, total dissolved solids and turbidity of water samples were determined using $\mathrm{pH}$, electrical conductivity and turbidity meters. Nitrate, phosphate, fluoride and sulphate in water samples were determined by hydrazine reduction method, reaction with ammonium molybdate and ascorbic acid, spadns method, turbidimetric method respectively using UV/ Visible spectrophotometer in accordance with APHA 4500. Potassium and sodium were analysed with flame atomic absorption spectrophotometer (FAAS) in accordance with APHA (1998).

Microbial analysis was done in accordance with American Public Health Association (APHA) (1998) standard 


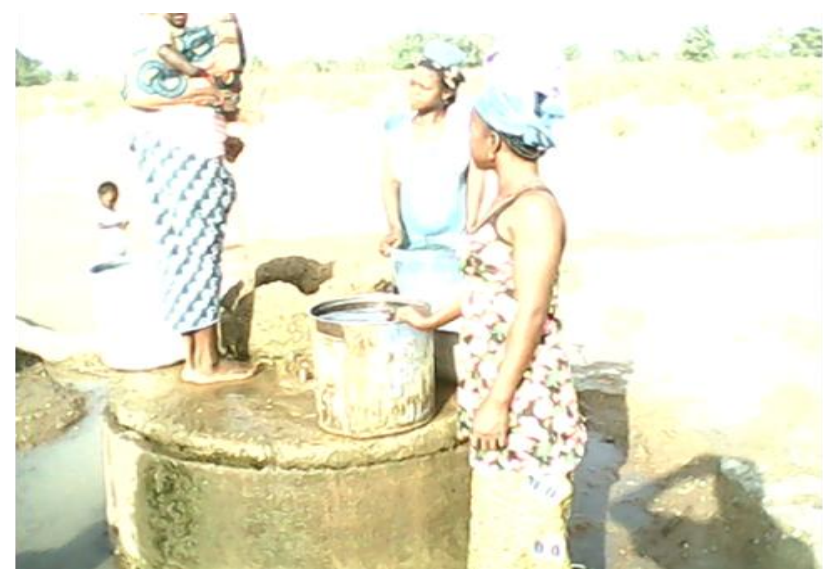

Plate 1: Some of the practices observed in Janga

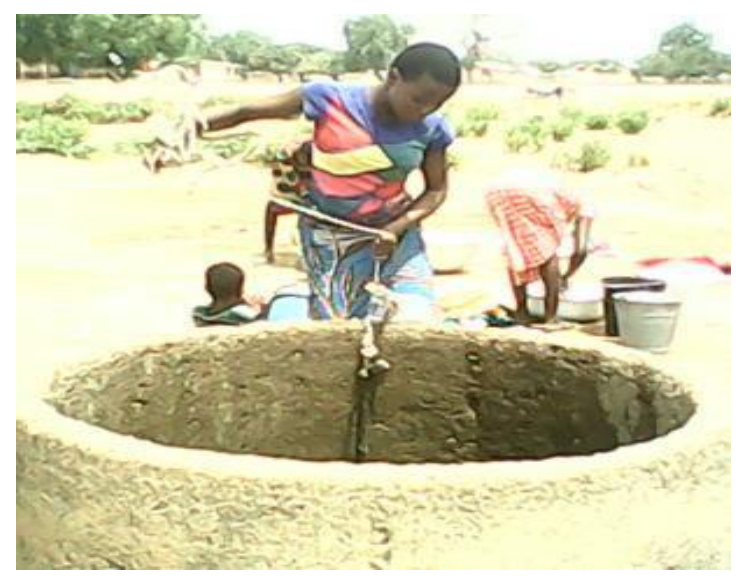

Plate 2: Hand-dug well without cover

Table 1. Summary results for the hand-dug wells parameters

\begin{tabular}{|c|c|c|c|c|c|c|}
\hline Parameters & Min & Max & Mean & STD & WHO Guide line & Unit \\
\hline TDS & 60 & 263 & 151.80 & 80.29 & 1000 & $\mathrm{mg} / \mathrm{l}$ \\
\hline E. conductivity & 99 & 438 & 252.17 & 133.12 & - & $\mu \mathrm{S} / \mathrm{cm}$ \\
\hline $\mathrm{pH}$ & 6.70 & 6.94 & 6.79 & 0.09 & $6.5-8.5$ & $\mathrm{pH}$-unit \\
\hline Total alkalinity & 12 & 92 & 43.50 & 23.52 & 1000 & $\mathrm{mg} / \mathrm{l}$ \\
\hline Bicarbonate & 14.60 & 112 & 53.03 & 28.63 & - & $\mathrm{mg} / \mathrm{l}$ \\
\hline Sulphate & 0.40 & 38.71 & 7.65 & 13.47 & 400 & $\mathrm{mg} / \mathrm{l}$ \\
\hline Chloride & 3.94 & 46.70 & 25.14 & 15.60 & 250 & $\mathrm{mg} / \mathrm{g}$ \\
\hline Nitrate & 0.02 & 1.94 & 0.54 & 0.68 & 10 & $\mathrm{mg} / \mathrm{l}$ \\
\hline Phosphate & 0.001 & 0.40 & 0.20 & 0.17 & 2.50 & $\mathrm{mg} / \mathrm{l}$ \\
\hline Fluoride & 0.01 & 1.22 & 0.54 & 0.53 & 1.50 & $\mathrm{mg} / \mathrm{l}$ \\
\hline Calcium & 6.41 & 40.10 & 21.59 & 13.11 & 200 & $\mathrm{mg} / \mathrm{l}$ \\
\hline Magnesium & 2.9 & 31.10 & 10.35 & 9.68 & 150 & $\mathrm{mg} / \mathrm{l}$ \\
\hline Sodium & 8.3 & 39.50 & 17.48 & 10.65 & 200 & $\mathrm{mg} / \mathrm{l}$ \\
\hline Potassium & 2.2 & 9.40 & 5.37 & 2.58 & 30 & $\mathrm{mg} / \mathrm{l}$ \\
\hline Turbidity & 2 & 9 & 4.5 & 2.50 & 5 & NTU \\
\hline Temperature & 28.20 & 28.80 & 28.47 & 0.19 & - & ${ }^{\circ} \mathrm{C}$ \\
\hline Total hardness & 28 & 202 & 94.50 & 60.99 & & $\mathrm{mg} / \mathrm{l}$ \\
\hline Total coliform & 0 & 2411 & 1012.92 & 717.88 & 0 & $\mathrm{cfu} / 100 \mathrm{ml}$ \\
\hline Faecal coliform & 0 & 482 & 135.08 & 187.55 & 0 & $\mathrm{cfu} / 100 \mathrm{ml}$ \\
\hline E. coli & 0 & 90 & 22.58 & 30.54 & 0 & $\mathrm{cfu} / 100 \mathrm{ml}$ \\
\hline
\end{tabular}

procedures. Membrane filtration technique was used to determine total coliforms, faecal coliforms and Escherichia coli in accordance with APHA 9222A, 9222D and 9260F. Filtration unit comprising of Erlenmeyer flask, vacuum source and porous support were assembled and with the aid of a flame-sterilized forceps, a sterile membrane filter $(0.45 \mu \mathrm{m}$ Millipore $)$ was placed on the porous support. The upper funnel was placed in position and secured with appropriate clamps in a Millipore machine. $100 \mathrm{ml}$ of sampled well water was aseptically poured into the upper funnel and suction applied to create a vacuum. After the sample was passed through the membrane filter, the filtration unit was taken apart and with the aid of a sterile forceps the membrane filter was placed in the Petri dish containing selective media for various parameters: M-Endo for total coliform, M-FC for Faecal coliform and Hi-Chrome agar for E. coli. Clamps, forceps were usually sterile prior to use for the next sample. All plates were incubated in inverted position at $37 \pm 2{ }^{\circ} \mathrm{C}$ (total coliform, Escherichia coli) and $44 \pm 2{ }^{\circ} \mathrm{C}$ (faecal coliform) for $18-24$ hours.

Water sample results were subjected to Pearson's significant correlation analysis using SPSS version 16 to determine the mutual relationship that exist between the parameters.

\section{RESULTS AND DISCUSSION}

Total dissolved solid (TDS) is a measure of total inorganic and organic substances dissolved in water (ANZECC, 2000). It is one of the characteristics, which decides the quality of drinking water. TDS values recorded ranged between 60 to $263 \mathrm{mg} / \mathrm{l}$ with a mean value of $150 \pm 80.29 \mathrm{mg} / \mathrm{l}$ (Table 1) that were less than WHO standard of $1000 \mathrm{mg} / \mathrm{l}$ for 


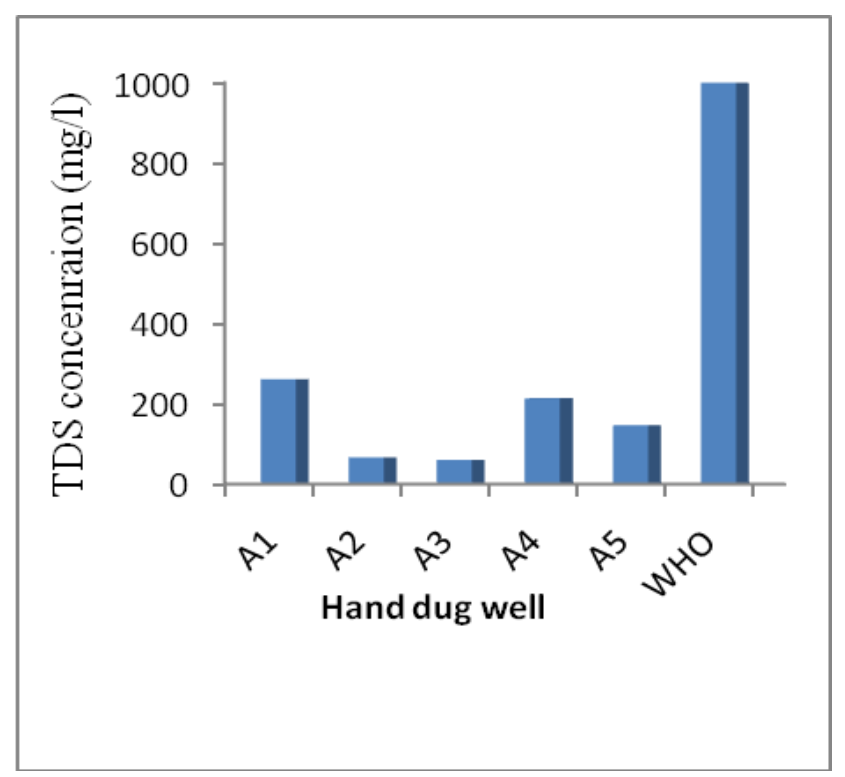

Figure 1: TDS mean cencentrations for the hand dug wells

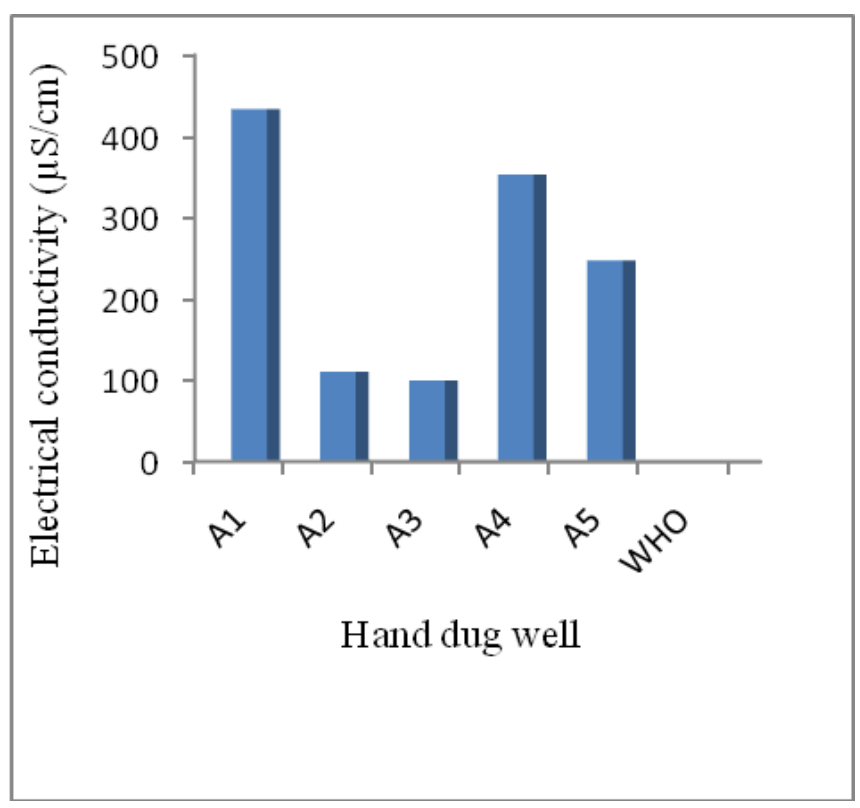

Figure 2: Electrical conductivity of hand dug well samples

drinking water. WHO (2004) reported that water with a TDS level less than $600 \mathrm{mg} / \mathrm{l}$ is more palatable and generally considered to be good whilst at level greater than $1000 \mathrm{mg} / \mathrm{l}$ implies significantly and increasing unpalatable. Hence, the hand-dug water is of good quality and palatable since the values are all less than $600 \mathrm{mg} / \mathrm{l}$. Well A1 recorded the highest total dissolved solid which could be attributed to the organic and inorganic materials leaching into the well, since it was closed to refuse dump and other domestic activities such as washing of cloths.

Electrical conductivity (EC) values recorded ranged from 99 to $439 \mu \mathrm{S} / \mathrm{cm}$ with a mean value of $249 \pm 133.12 \mu \mathrm{S} / \mathrm{cm}$ that falls within WHO permissible limit for potability (Table

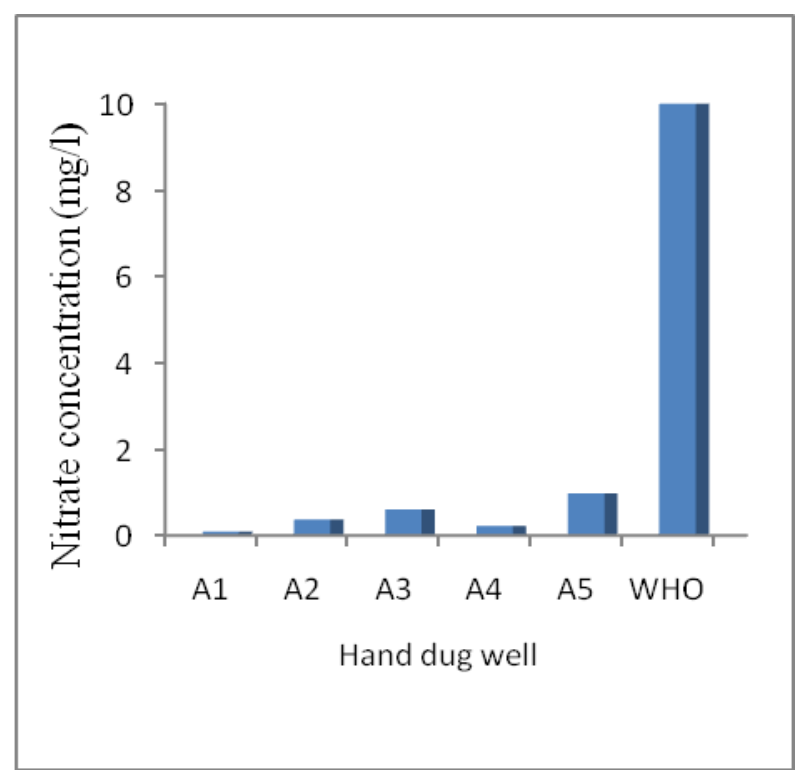

Figure 3: Nitrate mean concentrations for hand dug well

1). The electrical conductivity values are higher as compare to conductivity values that ranged from 46 to $282 \mu \mathrm{S} / \mathrm{cm}$ reported by Nkansah et al. (2010) who studied hand-dug wells in Kumasi metropolis, Ghana. EC strongly correlated with TDS, calcium, sodium, turbidity and total coliform (Table 2) suggesting each pair have a common source of contamination. Figure 1 and 2 are TDS and EC means values recorded from hand-dug wells.

The study recorded $\mathrm{pH}$ values that ranged from 6.70 to $6.94 \mathrm{pH}$-unit with a mean value of $6.78 \pm 0.09 \mathrm{pH}$-unit (Table $1)$. Generally, $\mathrm{pH}$ values of the hand-dug wells were within WHO limits for potability. The hand-dug wells studied were not acidic for potability and cannot cause health problem like acidosis. There was a strong positive correlation between magnesium and $\mathrm{pH}$ at 5\% significant level indicating common source of contamination (Table 2). Similar pH values were reported by Nkansah et al. (2010) who studied hand-dug wells in Kumasi metropolis, Ghana. Figure 3 above is $\mathrm{pH}$ means values recorded from hand-dug wells.

Total hardness concentration values recorded ranged between 28.0 to $202.0 \mathrm{mg} / \mathrm{l}$ with a mean value of $90.2 \pm$ $60.99 \mathrm{mg} / \mathrm{l}$ (Table 1). Figure 6 below is total hardness mean concentrations for the various sampled wells. The calcium values recorded ranged between 6.41 to $40.10 \mathrm{mg} / \mathrm{l}$ with a mean value of $21.30 \pm 13.11 \mathrm{mg} / \mathrm{l}$ (Table 1). Magnesium values recorded ranged from 2.90 to $31.10 \mathrm{mg} / \mathrm{l}$ with a mean value of $8.45 \pm 9.68 \mathrm{mg} / \mathrm{l}$ (Table 1 ). Total hardness, calcium and magnesium concentrations of the hand-dug wells are within WHO limits for potability.

Calcium and magnesium are important elements in human nutrition. Calcium is required for blood clotting and strong bones; whilst magnesium acts as a cofactor and activator of hundreds of enzymatic reactions. The presence of calcium and magnesium ions makes water hard.

However, there is no evidence of adverse effects 


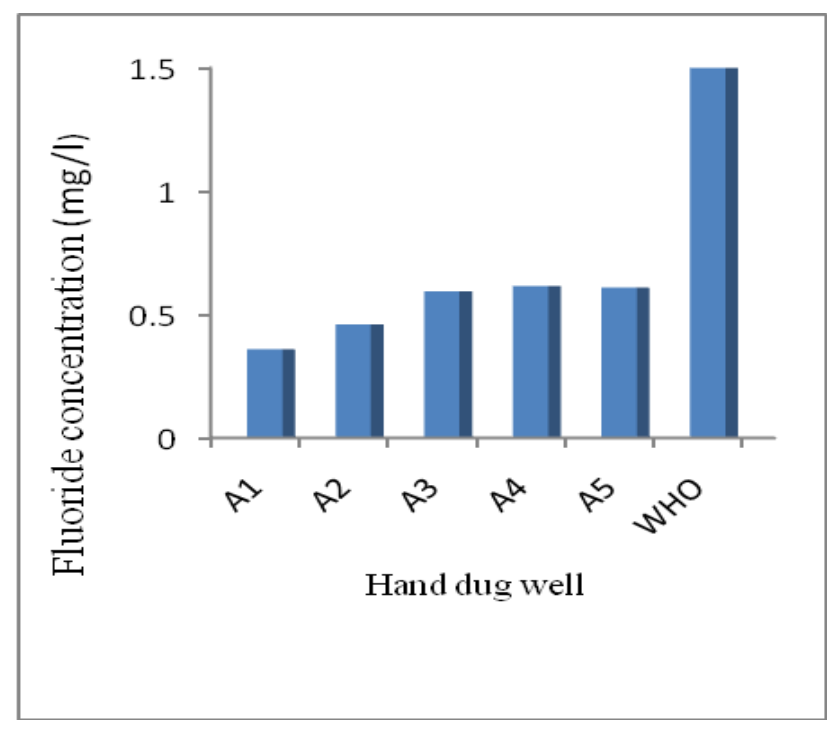

Figure 4: Fluoride concentration means for hand dug well

specifically attributable to these ions in drinking water (Oyerlude, 2013). Water has been classified on the basis of hardness as follows by WHO; soft ( 0 to $50 \mathrm{mg} \mathrm{CaCO} / \mathrm{l})$, moderate soft (50 to $100 \mathrm{mg} \mathrm{CaCO}_{3} / \mathrm{l}$, slightly hard (100 to $150 \mathrm{mg} \mathrm{CaCO} / \mathrm{l}$ ), moderate hard (150 to $200 \mathrm{mg} \mathrm{CaCO}_{3 / 1}$ ), hard (200 to $300 \mathrm{mg} \mathrm{CaCO} / \mathrm{l})$ and very hard (over $300 \mathrm{mg}$ $\left.\mathrm{CaCO}_{3} / \mathrm{l}\right)(\mathrm{WHO}, 1984)$. Based on this, some of the hand-dug wells water studied are hard which implies it contains enough calcium that is essential for normal growth, health and indicate palatability of the hand-dug well water.

Alkalinity concentration of sampled wells was observed to be far below WHO standard. However, the alkalinity nature of well A2 could be due to discharge of ashes, waste water containing detergents such as soap which leach into the well. Generally, alkalinity is caused by $\mathrm{HCO}_{3}, \mathrm{CO}_{3}{ }^{2-}$ and $\mathrm{OH}^{-}$component in a raw or treated water supply (Ayodele and Aturamu, 2011). High pH's above 8.5 are often caused by high bicarbonate $\left(\mathrm{HCO}_{3}{ }^{-}\right)$and carbonate $\left(\mathrm{CO}_{3}{ }^{2-}\right)$ concentrations, known as alkalinity. High carbonates cause calcium and magnesium ions to form insoluble minerals leaving sodium as the dominant ion in solution (Musah and Ahanonu, 2013).

Chloride content of the hand-dug wells samples ranged from 3.94 to $46.70 \mathrm{mg} / \mathrm{l}$ with a mean value of $25.14 \pm 15.60$ $\mathrm{mg} / \mathrm{l}$ (Table 1). These values are less than WHO desirable limit of $250 \mathrm{mg} / \mathrm{l}$ for drinking water. The sulphate concentration of the hand-dug wells samples ranged from 0.40 to $38.77 \mathrm{mg} / \mathrm{l}$ with a mean value of $7.65 \pm 13.47 \mathrm{mg} / \mathrm{l}$ (Table 1). These values are less than WHO desirable limit of $400 \mathrm{mg} / \mathrm{l}$ for drinking water. Phosphate concentration of the hand-dug wells samples ranged from 0.001 to $0.40 \mathrm{mg} / \mathrm{l}$ with a mean value of $0.20 \pm 0.17 \mathrm{mg} / \mathrm{l}$ (Table 1). These values are less than WHO desirable limit of $2.5 \mathrm{mg} / \mathrm{l}$ for drinking water. Nitrate values recorded ranged from 0.09 to $1.94 \mathrm{mg} / \mathrm{l}$ with a mean value of $0.42 \pm 0.68 \mathrm{mg} / \mathrm{l}$ (Table 1 ).

Figure 3 above is nitrate mean concentration for the various sampled wells. High concentrations of $\mathrm{NO}_{3}{ }^{-}$may give rise to potential health risks such as methmoglobinemia or 'blue-baby-syndrome' particularly in pregnant women and bottle-fed infants respectively. $\mathrm{NO}_{3}^{-}$ at elevated concentrations is also known to result in cyanosis in infants (Nkansah et al., 2010). Source of nitrate contamination could be attributed to runoff of agrochemicals from agricultural farmlands during heavy rain. Even though all the wells did not exceed WHO standard, well A5 was recorded the highest nitrate concentration because of aerobic decomposition of organic materials such as plant and other substances since the well located within vegetation cover.

Fluoride values recorded ranged from 0.01 to $1.22 \mathrm{mg} / \mathrm{l}$ with a mean value of $0.52 \pm 0.53 \mathrm{mg} / \mathrm{l}$ (Table 1). Figure 4 below is fluoride mean values for the various sampled wells. Drinking water containing 0.70 to $1.20 \mathrm{mg} / \mathrm{l}$ natural or added fluoride is helpful to children during the time they are developing permanent teeth (Nemerow et al., 2009). Mottling and discoloration of teeth in children has been reported at concentrations above $1.5 \mathrm{mg} / \mathrm{l}$ especially greater than $4 \mathrm{mg} / \mathrm{l}$. The study revealed that fluoride values recorded may not have health effect on rural folks as fluoride values were within WHO standard of $1.5 \mathrm{mg} / \mathrm{l}$.

Turbidity values recorded ranged between 2.0 to $9.0 \mathrm{NTU}$ with a mean value of $4.43 \pm 2.50$ NTU (Table 1). Figure 5 below is turbidity mean values for the various sampled wells. In general, the turbidity of the wells was predominantly below WHO recommended guideline value of 5.0 NTU except A2 and A3. This is because well A2 and A3 were located opposite to each other and were very close to a small street used by vehicles and humans where a quantum of dust could be released into the water. These wells were also located a little bit away from the community and were within a vegetation land where dead materials from the vegetation could fall into the wells which could cause the high level of turbidity. High turbidity can stimulate bacteria growth, which causes problems with treatment processes.

The present study recorded turbidity values that are a bit higher that of Shittu et al. (2008) who reported turbidity values that ranged from 2.5 to 7.0 NTU in dug well water samples in Abeokuta, Nigeria. According to Musah and Ahanonu (2013), turbidity has been described as a relatively crude method of detecting a wide variety of particles from a wide assortment of sources as it provides no information about the nature of the particles. The added presence of turbidity increases the apparent, but not the true colour of water. Turbidity correlated negatively with TDS, EC, $\mathrm{Ca}^{2+}$ and $\mathrm{K}$ (Table 2) this implies their contaminants in wells water are common. Temperature values recorded in the study ranged from 28.2 to $28.8^{\circ} \mathrm{C}$ with a mean of $28.5^{\circ} \mathrm{C}$ (Table 1) which can support the growth of mesophilic microorganisms which requires temperature ranges of 20 to $45^{\circ} \mathrm{C}$ (Prescott et al., 1999). It is stated that high water temperature enhances the growth of microorganisms (WHO, 2008).

Total coliforms values recorded ranged from 0.0 to $2.41 \times$ 


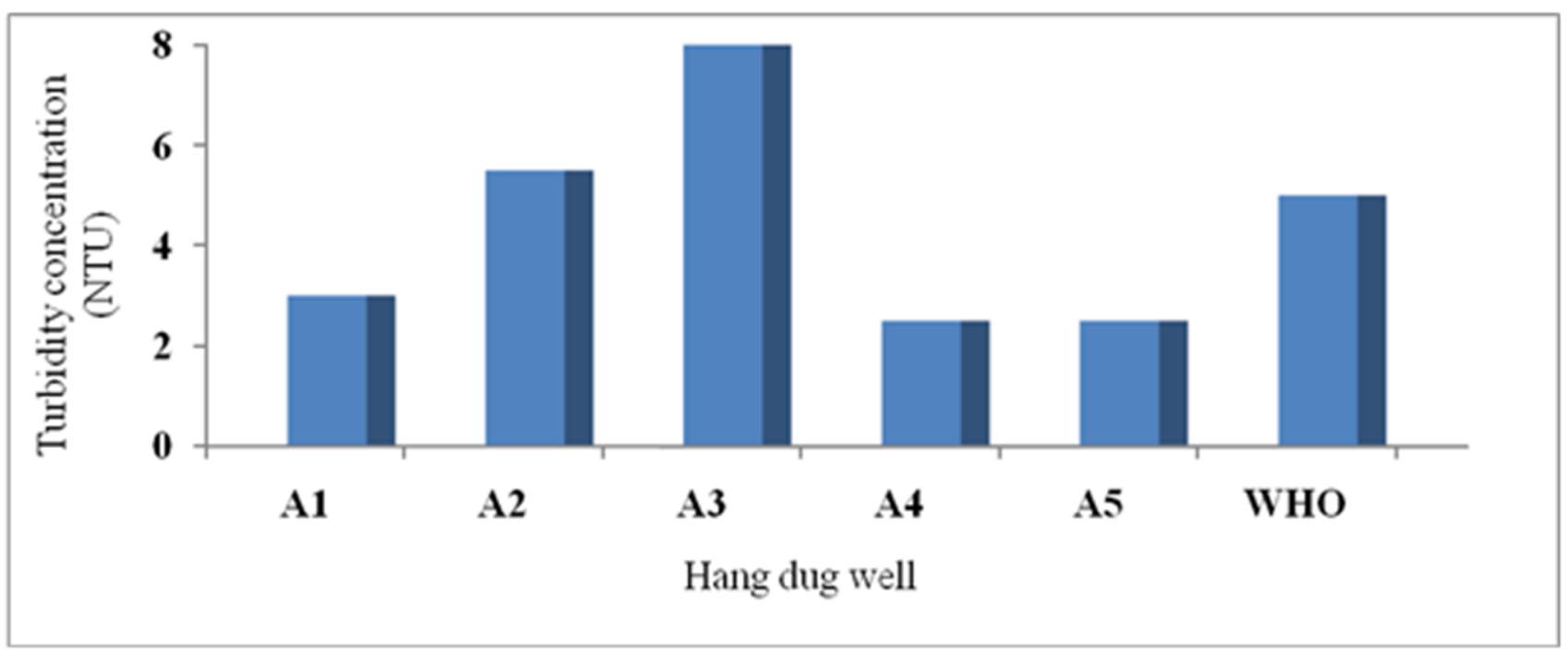

Figure 5: Turbidity concentration means for hand dug wells

Table 2. Correlation analysis of parameters of the hand-dug wells water samples

\begin{tabular}{|c|c|c|c|c|c|c|c|c|c|c|c|}
\hline Parameter & TDS & EC & $\mathrm{NO}_{3}$ & $\mathrm{PO}_{4}$ & Fl & $\mathrm{Ca}^{2+}$ & $\mathrm{Mg}^{2+}$ & $\mathrm{Na}$ & $\mathbf{K}$ & Turb & TC \\
\hline TDS & 1 & & & & & & & & & & \\
\hline EC & $1.0^{* *}$ & 1 & & & & & & & & & \\
\hline $\mathrm{NO}_{3}$ & -0.25 & -0.26 & 1 & & & & & & & & \\
\hline $\mathrm{PO}_{4}$ & -0.03 & -0.02 & $-0.71^{*}$ & 1 & & & & & & & \\
\hline $\mathrm{Fl}$ & -0.07 & -0.06 & $-0.66^{*}$ & $.95^{* *}$ & 1 & & & & & & \\
\hline $\mathrm{Ca}^{2+}$ & $0.90^{* *}$ & $0.91^{* *}$ & -0.12 & 0.04 & 0.05 & 1 & & & & & \\
\hline $\mathrm{Mg}^{2+}$ & 0.38 & 0.38 & $0.66^{*}$ & -0.50 & -0.48 & 0.43 & 1 & & & & \\
\hline $\mathrm{Na}$ & $0.78^{* *}$ & $0.78^{* *}$ & -0.31 & -0.20 & -0.21 & $0.70^{*}$ & 0.05 & 1 & & & \\
\hline K & $0.87^{* *}$ & $0.87^{* *}$ & -0.23 & 0.15 & 0.16 & $0.78^{* *}$ & 0.36 & 0.45 & 1 & & \\
\hline Turb & $-0.74^{*}$ & $-0.75^{*}$ & 0.29 & -0.30 & -0.29 & $-0.76^{*}$ & -0.38 & -0.33 & $-0.84 * *$ & 1 & \\
\hline TC & $0.75^{*}$ & $0.75^{*}$ & 0.33 & -0.28 & -0.27 & $0.84^{* *}$ & $0.86^{* *}$ & 0.43 & $0.67^{*}$ & $-0.67^{*}$ & 1 \\
\hline
\end{tabular}

${ }^{* *}$ Correlation is significant at the 0.01 level (2-tailed)

* Correlation is significant at the 0.05 level (2-tailed)

$10^{3} \mathrm{cfu} / 100 \mathrm{ml}$ with a mean value of $9.23 \times 10^{2} \pm 717.88$ cfu/ $100 \mathrm{ml}$ (Table 1). Figure 6 below is total coliform mean counts for various sampled wells. Total coliform values exceeded WHO guideline value of $0.0 \mathrm{CFU} / 100 \mathrm{ml}$ for potability. Well A1 and A4 had high total coliforms counts simply because of their proximity to refuse damp within the community. Generally, all the wells were operated under extremely poor sanitary conditions as domestic wastes such as food waste, and other particles were deposited. This therefore poses health threats to consumers of the dug wells. The availability and purity of groundwater are affected by location, construction and operation of wells (Egbulem, 2003). According to Adetunde et al. (2011), the use of contaminated drawers/ containers to draw water from some well is another source of contamination.

Faecal coliforms values recorded ranged between 0.0 to $4.82 \times 10^{2} \mathrm{cfu} / 100 \mathrm{ml}$ with a mean value of $1.217 \times 10^{2} \pm$ $187.55 \mathrm{cfu} / 100 \mathrm{ml}$ (Table 1). Figure 7 below is faecal coliform mean counts for various sampled wells. The higher level of faecal coliform present in well A1, A3 and A4 is due to open vegetation around the well which animals usually feed on and defecate. This confirms the assertion made by Tiedemann et al. (1988), that the proximity of domestic and grazing animals to water sources play role in severity of faecal contamination of water sources. The present study recorded faecal coliform counts that are higher than that of Olowe et al. (2005) in hand-dug well water samples. Presence of faecal coliforms in drinking water is associated with fresh faecal contamination form sewage or animal hence making the well water unwholesome. This is an indication of higher risk of pathogens that can cause disease burden that include dysentery, typhoid fever, viral and bacterial gastroenteritis and hepatitis $\mathrm{A}$.

E. coli values recorded ranged between 0.0 to $9.0 \times 10^{1}$ $\mathrm{cfu} / 100 \mathrm{ml}$ with a mean value of $1.9 \times 10^{1} \pm 30.54 \mathrm{cfu} / 100$ $\mathrm{ml}$ (Table 1). Figure 8 below is Escherichia coli concentration means for various sampled wells. E. coli levels in the wells were above WHO permissible limit of 0.0 


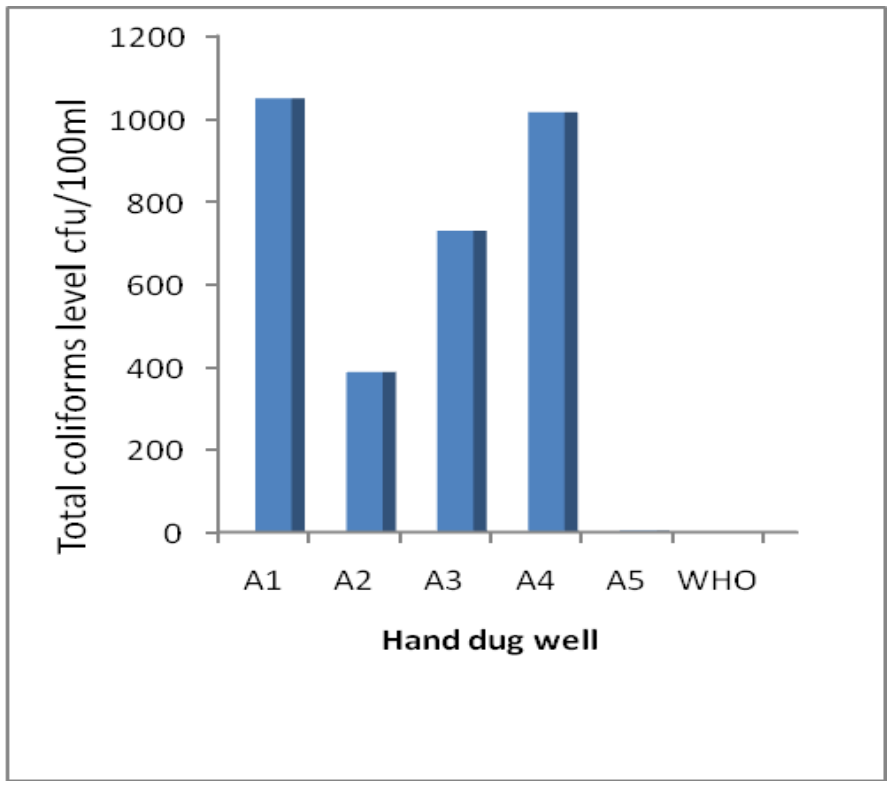

Figure 6: Total coliform counts for hand dug wells

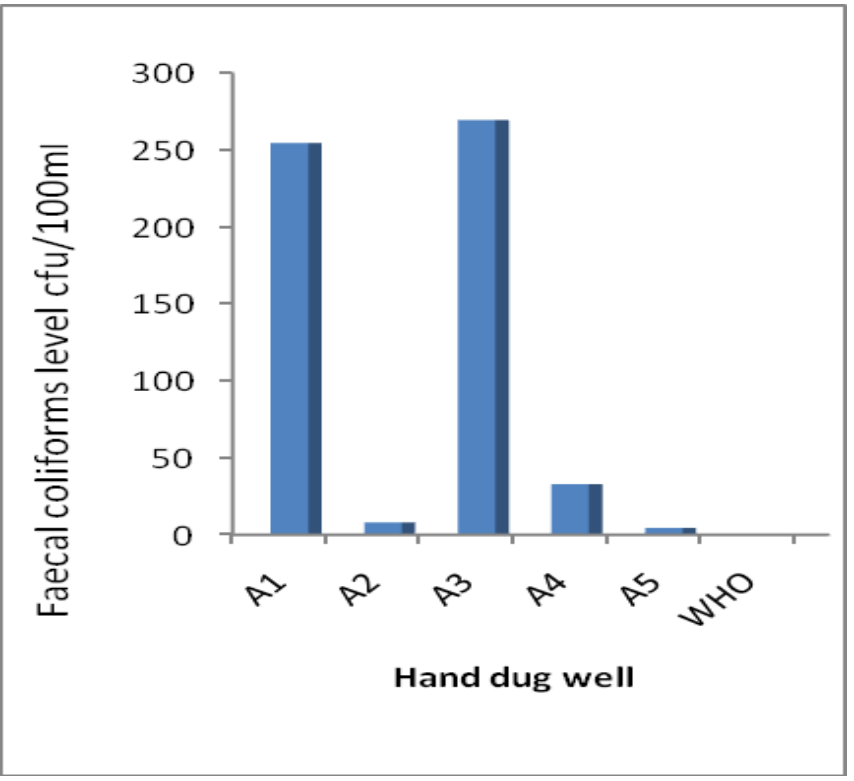

Figure 7: Faecal coliform counts for hand

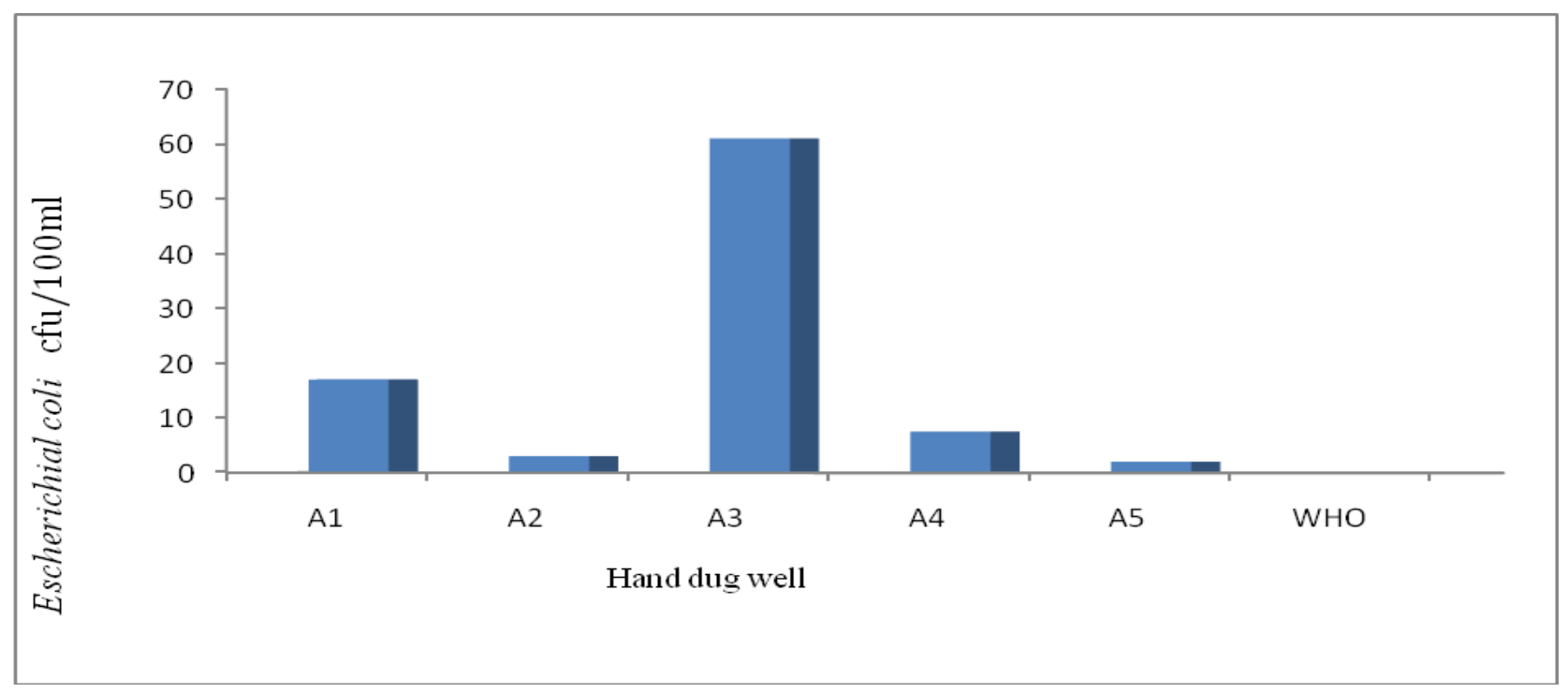

Figure 8: E. coli counts for hand dug well

$\mathrm{cfu} / 100 \mathrm{ml}$ for potability. E. coli is present in very high numbers in human and animal faeces and its presence provides conclusive evidence of fresh faecal pollution (WHO, 2004). Hence, its presence in the hand-dug wells poses health risk to residents of Janga. E. coli is the only microbial indicator associated with public health significance (Verhille, 2013). It is the most reliable indicator of enteric diseases and indicator of choice to indicate occurrence of recent faecal contamination in drinking water systems (Tallon et al., 2005). The high level of $E$. coli in well A3 could be attributed to its high turbidity levels. As it was reported by Shittu et al. (2008) that high turbidity is often associated with higher levels of disease causing microorganism such as bacteria and other parasites. The hand-dug wells water which is mostly used by residents of Janga is not risk free from disease burdens. Typhoid fever and disease cases that are annually reported in Janga polyclinic (Table 3) show poor water quality. This therefore threatens Ghana desire to meet the millennium development goal 7.

\section{CONCLUSIONS}

The hand-dug wells water analysed in the present study is suitable for drinking in terms of physico-chemical quality. 
Table 3. Disease cases reported by Janga Polyclinic

\begin{tabular}{lcccccc}
\hline & \multicolumn{9}{c}{ Year } & $\mathbf{2 0 1 3}$ & $\mathbf{2 0 1 4}$ \\
\cline { 2 - 7 } Disease & $\mathbf{2 0 0 9}$ & $\mathbf{2 0 1 0}$ & $\mathbf{2 0 1 1}$ & $\mathbf{2 0 1 2}$ & $\mathbf{2 0 1 3}$ & 72 \\
\hline Typhoid Fever & 0 & 0 & 5 & 196 & 169 & 933 \\
Diarrhoea Diseases & 157 & 122 & 354 & 169 & 604 & 9 \\
Intestinal Worms & 0 & 0 & 0 & 0 & 0 & 9 \\
\hline
\end{tabular}

Source (Tamale Health Directorate, 2014)

As the tested parameters were within WHO guideline values for drinking water except turbidity. However, there were high coliform bacteria counts in the hand-dug wells samples which were extremely above WHO recommended guideline values for drinking water. The high count of coliform bacteria indicates poor sanitary conditions in Janga, arising from poor handling of domestic wastes, especially garbage and sewage. The implication is that water from hand-dug wells in the Janga is neither safe nor suitable for direct human consumption. There should be concern since drinking this unwholesome hand-dug well water could lead to disease burden and it also indicates that meeting the millennium development goal 7 will be a meagre. Based on the findings of the study, it is therefore recommended that hand-dug wells water should be treated against bacteria before usage in order to meet the millennium development goal 7. The residents of Janga and its catchment should be informed about the implication of their poor sanitary conditions and its implication to their own well-being. This will go a long way to reduce incidences of water pollution and the associated water borne diseases.

\section{ACKNOWLEDGMENTS}

We wish to express our profound gratitude to the staff of CSIR- Water Research Institute, Tamale for the timely analysis of the samples.

\section{Conflict of interests}

The authors declare that there is no conflict of interests regarding the publication of this paper.

\section{REFERENCES}

Adefemi SO (2012). Physicochemical and microbiological assessment of groundwater from Ijan-Ekiti South Western Nigeria. Environ. Res. J., 6: 316-320.

Adekunle AS (2008). Impact of industrial effluent on quality Adetunde LA, Glover RLK, Oguntola GO (2011). Assessment of the groundwater quality in Ogbomoso town ship of Oyo state of Nigeria. IJRRAS, 8(1): 115-122.

American Public Health Association (APHA) (1998). Standard methods for examination of water and waste water, $20^{\text {th }}$ Ed. American Public Health Association Inc, New York. American Water Work Associated (AWWA).

ANZECC (2000). Australian and New Zealand Environment and Conservation Council. Water Quality Guidelines.

Ayodele OS, Aturamu AO (2011). Potable status of some hand-dug wells in Ekiti State, South western Nigeria. Int. J. Sci. Technol., 1: 102 - 109.

Egbulem BN (2003). Shallow groundwater monitoring. Proceedings of the $29^{\text {th }}$ Water, Engineering and Development Centre - UK. (WEDC) International conference, held in Abuja- Nigeria. Published by WEDC, London. pp 188- 189.

Gadgil A (1998). Drinking water in developing countries. Annual Review of Energy and the Environment, 23: 253286.

Musah JJ, Ahanonu JJ (2010). Quality assessment of shallow groundwater in some selected Agrarian communities in Patigi Local Government Area, Nigeria. Department of Agricultural and Bioresources Engineering, Federal University of Technology, PMB65, Minna, Nigeria.

Nemerow NL, Agardy FJ, Salvato JA (2009). Environmental Engineering: Water, wastewater, soil, and groundwater treatment and remediation. Sixth, editor: Wiley.

Nkansah MA, Boadu NO, Badu M (2010). Assessment of quality of water from hand-dug wells in Ghana. Environmental health insight, 4: 7- 12.

Obiri-Danso K, Adjei B, Stanley KN, Jones K (2009). Microbiological quality and metals in wells and boreholes water in some peri-urban communities in Kumasi, Ghana. Afri. J. Environ. Sci. Technol., 3(1): 055-066.

of wells water within As a Dam industrial Estate, llorin, Nigeria. Natural and Science, 6(3):1-5.

Olowe OA, Ojurongbe 0, Opaleye 00, Adedosu OT, Olowe RA, Eniola KIT (2005). Bacteriological quality of water in Osogbo metropolis. Afri. J. Clinical Experim. Microbiol., 6: 220 - 221.

Oyelude EO, Densu AE, Yankey E (2013). Quality of groundwater in Kassena-Nankana district, Ghana and its health implications. Advances in Appl. Sci. Res., 4(4): 442448.

Palaniappan M, Lang M, Gleick PH (2008). A review of decision-making support tools in the water, sanitation, and hygiene sector. Woodrow Wilson International Center for Scholars, Spring.

Prescott LM, Harley JP, Klein DA (1999). The influence of environmental factors on growth. Microbiology. Fourth Edition. McGraw-Hill Companies, Inc., USA, pp 123-132. 
Shittu OB, Olaiton JO, Musah TS (2008). Physico-chemical and bacteriological analysis of water used for drinking and swimming purposes in Abeokuta, Nigeria. Afri. J. Biomed. Res.,11: 285-290.

Tallon P, Magajna B, Lofranco C, Leung KT (2005). Microbial indicators of faecal contamination in water: a current perspective. Water Air Soil Pollut., 166: 139-166.

Tay CK (2007). Chemical characteristics of ground water in the Akatsi and Ketu Districts of the Volta Region, Ghana. West Africa Journal of Applied Ecology, 11: 1-23.

Tiedemann AR, Higgins DA, Quigley TM, Sanderson HR, Bohn CC (1988). Bacterial water quality responses to four grazing strategies comparisons with Oregon standards. J. Environ., 17: 492 - 498.

Verhille S (2013). Understanding microbial indicators for drinking water assessment: interpretation of test results and public health significance. National Collaborating Centre for Environmental Health.
WHO (1984). Guidelines of drinking water quality, Vol. 1, Recommendations, WHO Geneva, pp. 19-115.

WHO (2004). Guidelines for Drinking-water Quality. Volume 1 WHO - Geneva.

WHO (2008). Safe water and global health. www.who/int/features/qa/70/en/index.htm. (Accessed June 12, 2013).

WHO, UNICEF (2012). Progress on sanitation and drinking water: 2012 Update; World Health Organisation /UNICEF: Geneva, Switzerland.

World Health Organisation (WHO) (2011). Progress on sanitation and drinking water. Available online at: http://www.wssinfo.org/fileadmin/user_upload/resourc es/1278061137JMP_report_2010en.pdf. (Accessed June 12, 2013).

Yakubu S (2013). Assessment of water quality of hand-dug wells in Zaria LGA of Kaduna state, Nigeria. Int. J. Eng. Sci., 2(11): 01-04. 